\title{
Development of Active Solids Activator (Pellet) Using Local Culture from Badung River, Bali to Enhance Nitrification Process of Goat Wastewater
}

\author{
I Wayan Budiarsa Suyasa ${ }^{a, *}$, Gede Adi Wiguna Sudiartha ${ }^{b}$ \\ ${ }^{a}$ Laboratory of Environmental Chemistry, Faculty of Mathematics and Science, Udayana University, Bali, 80361, Indonesia \\ ${ }^{b}$ Environmental Engineering Study Programme, Faculty of Engineering, Udayana University, Bali, 80361, Indonesia \\ Corresponding author: *budiarsa_suyasa@unud.ac.id
}

\begin{abstract}
Goat urine wastewater that is disposed of without being processed will certainly cause environmental pollution. Therefore it is necessary to process the livestock waste. Processing goat urine into fertilizer needs to be done by converting ammonia to nitrate, or what is called the nitrification process. Nitrification takes place in two stages of oxidation, the first is the oxidation of ammonium to nitrite, and the second is the oxidation of nitrite to nitrate with the help of oxygen. The materials used in this study were $\left(\mathrm{NH}_{4}\right)_{2} \mathrm{SO}_{4}$, $\mathrm{K}_{2} \mathrm{HPO}_{4}, \mathrm{NaHCO}_{3}, \mathrm{Na}_{2} \mathrm{CO}_{3}, \mathrm{MgSO}_{4} .7 \mathrm{H}_{2} \mathrm{O}, \mathrm{FeSO}_{4} .7 \mathrm{H}_{2} \mathrm{O}, \mathrm{CaCl}_{2} .2 \mathrm{H}_{2} \mathrm{O}, \mathrm{ZnSO}_{4}, \mathrm{NaCl}, \mathrm{H}_{2} \mathrm{SO}_{4}, \mathrm{NaNO}_{2}, \mathrm{KNO}_{3}, \mathrm{NH}_{4} \mathrm{Cl}_{1}, \mathrm{Na}_{2} \mathrm{~S}_{2} \mathrm{O}_{3}(\mathrm{solution}$ distilled water, filter paper, Rochell salts, Nessler reagent, $\mathrm{N}$ - (1-naphthyl) -ethylenediamine dihydrochloride (NED dihydrochloride) solution, sulfanilamide solution, sulfuric acid brucine solution, NPK fertilizer, glucose, urea fertilizer, TSP fertilizer, KCI fertilizer, cornflour, tofu dregs. Goat livestock waste, namely goat urine, was taken from one of the farms in North Denpasar, and sediment sampling was carried out in the Badung river next to the goat farm. According to the result, the best medium for ammonia oxidizers pellets was Ammonia Oxidizer Media II (media for pellet b) which was built of 10 grams of NPK fertilizer, 10 grams of glucose, and 5 grams of $\mathrm{NH}_{4} \mathrm{Cl}$ powder. Furthermore, the sample performed the highest nitrite removal with a pellet dose of $20 \%$ (w/v) (pellet b) and the measurement time at 18 hours, with an average nitrite concentration of three repetitions $2.3992 \mathrm{mg} / \mathrm{L}$.
\end{abstract}

Keywords — Active suspension; goat livestock wastewater; nitrification; oxidizer media; pellet.

\section{INTRODUCTION}

Faced with tremendous consumption of livestock products, domestic stocking, and small-scale livestock farms could not multiply the production capacity to meet the population's daily needs [1]. To improve production capacity, more livestock farms were built and operated, consequently increasing number of livestock wastewater containing large amount of nutrients, heavy metals, organic matters, and pathogens discharged from farms [1]. Livestock wastewater contains high concentrations of nitrogen and phosphorus [2]. Goat urine is categorized as one of the livestock wastewaters. Goat urine contains $0.69 \%$ nitrogen $(\mathrm{N}), 2.09 \%$ phosphorus $(\mathrm{P}), 0.64 \%$ potassium $(\mathrm{K})$. Processing goat urine into fertilizer needs to be done by converting ammonia to nitrate, or what is called the nitrification process. Nitrification takes place in two stages of oxidation, the first is the oxidation of ammonium to nitrite and the second is the oxidation of nitrite to nitrate with the help of oxygen. Nitrification is a prerequisite for denitrification, wastewater treatment efficiency using biological nitrogen removal system depends upon microbial activities of two different bacterial groups in the nitrification phase: ammonia-oxidizing bacteria are responsible for the oxidization of ammonia of nitrite, then nitrite oxidizing bacteria convert nitrite to nitrate [3]. At each stage, it is carried out by a different bacterial genus, namely the first nitrification stage is carried out by Nitrosomonas bacteria and the second nitrification stage to convert nitrite into nitrate is carried out by Nitrobacter bacteria. The distribution of microbial community structures in nitrite-oxidizing bacteria (NOB) was separated by space rather than time or $\mathrm{C} / \mathrm{N}$ ratio except for Nitrobacter [4]. Oxidation of $\mathrm{NO}_{2}-\mathrm{N}$ to $\mathrm{NO}_{3}-\mathrm{N}$ depends mainly on NOB [5]. Prior to this research, there was research conducted by Vanotti and Hunt [6] that undertook a study about nitrifying treatment of pig wastewater with sludge that was acclimatized and immobilized in Acclimated Lagoon Nitrifying Sludge (ALNS) polymer pellets. The inorganic composition of 3 media used for the preparation of ALNS 
were $\left(\mathrm{NH}_{4}\right)_{2} \mathrm{SO}_{4} 300 \mathrm{mg} / \mathrm{L} ; \mathrm{K}_{2} \mathrm{HPO}_{4} 100 \mathrm{mg} / \mathrm{L} ; \mathrm{NaHCO}_{3}$ $1225 \mathrm{mg} / \mathrm{L} ; \mathrm{Na}_{2} \mathrm{CO}_{3} 359 \mathrm{mg} / \mathrm{L} ; \mathrm{MgSO}_{4} .7 \mathrm{H}_{2} \mathrm{O} 60 \mathrm{mg} / \mathrm{L}$; $\mathrm{FeSO}_{4} .7 \mathrm{H}_{2} \mathrm{O} 40 \mathrm{mg} / \mathrm{L}$; and $\mathrm{CaCl}_{2} .2 \mathrm{H}_{2} \mathrm{O} 40 \mathrm{mg} / \mathrm{L}$. The previous research used nitrifying sludge from seed biofilm sludge derived from surface soil of an overland flow field which provided nitrification treatment from anaerobic swine lagoon. Meanwhile, in our research, the sludge was taken from random sludge from Badung River to measure the capability of local sludge to cultivate NOB and its efficiency to perform the nitrification process of goat urine wastewater. As nutrients enrichment, several trace minerals were added such as $\mathrm{ZnSO}_{4}, \mathrm{NaCl}, \mathrm{H}_{2} \mathrm{SO}_{4}, \mathrm{NaNO}_{2}, \mathrm{KNO}_{3}, \mathrm{NH}_{4} \mathrm{Cl}$, $\mathrm{Na}_{2} \mathrm{~S}_{2} \mathrm{O}_{3}$.

The growth of microorganisms was observed according to the value of MLVSS (Mixed Liquor Volatile Suspended Solids). The time required for the oxidation of $\mathrm{NH}_{4}^{+}( \pm 210-$ $230 \mathrm{mg} / \mathrm{l})$ to $\mathrm{NO}_{3}{ }^{-}$using immobilized ALNS pellets was 14 hours. In the waste treatment that does not use immobilized ALNS pellets, it takes 10 days. Treatment of urine waste into $\mathrm{N}$ fertilizers by immobilizing the active suspension on ammonia oxidizers pellets. The pellets used in this research were different from previous studies, where previous researchers used polymer pellets while this research tried using organic pellets made from tofu pulp and corn flour.

This research will begin with the preparation of an active solution of ammonia oxidizers, namely by adding activated sludge exposed to 4 ammonias into several variations of the medium and then seeding ammonia-oxidizing bacteria. The active solution of ammonia oxidizers with the highest biomass will be used for the next process, namely immobilization of the active solution of ammonia oxidizers on pellets made from tofu and corn flour. This pellet was then applied to treat goat urine wastewater which was expected to provide an enormous amount of Nitrogen. The purpose of this study was to determine the best nutrient composition on the growth of biomass (Mixed Liquor Volatile Suspended Solids/MLVSS) of nitrifying microorganisms. Afterwards, the changes between nitrogen concentration before and after treatment would be used to determine the best dosage of ammonia oxidizers pellets to be applied for the nitrification process of urine to $\mathrm{N}$ fertilizer, and this research also aimed to define the most optimum processing time on the nitrification process of urine to $\mathrm{N}$ fertilizer.

\section{MATERIALS AND METHODS}

The materials used in this study were $\left(\mathrm{NH}_{4}\right)_{2} \mathrm{SO}_{4}, \mathrm{~K}_{2} \mathrm{HPO}_{4}$, $\mathrm{NaHCO}_{3}, \mathrm{Na}_{2} \mathrm{CO}_{3}, \mathrm{MgSO}_{4} .7 \mathrm{H}_{2} \mathrm{O}, \mathrm{FeSO}_{4} .7 \mathrm{H}_{2} \mathrm{O}, \mathrm{CaCl}_{2} .2 \mathrm{H}_{2} \mathrm{O}$, $\mathrm{ZnSO}_{4}, \mathrm{NaCl}, \mathrm{H}_{2} \mathrm{SO}_{4}, \mathrm{NaNO}_{2}, \mathrm{KNO}_{3}, \mathrm{NH}_{4} \mathrm{Cl}, \mathrm{Na}_{2} \mathrm{~S}_{2} \mathrm{O}_{3}$, distilled water, filter paper, Rochelle salts, Nessler reagent, $\mathrm{N}$ (1-naphthyl) -ethylenediamine dihydrochloride (NED dihydrochloride) solution, sulfanilamide solution, sulfuric acid brucine solution, NPK fertilizer, glucose, urea fertilizer, TSP fertilizer, $\mathrm{KCl}$ fertilizer, corn flour, tofu dregs. Goat livestock waste, namely goat urine, is taken from one of the farmlands on Jl. Maruti No. 5, North Denpasar, and sediment was taken from the Badung river next to the goat farm. The research was conducted at the Research Laboratory of the Department of Chemistry, Faculty of Mathematics and Natural Sciences, Udayana University. The detailed research methodology can be illustrated as in Fig. 1.

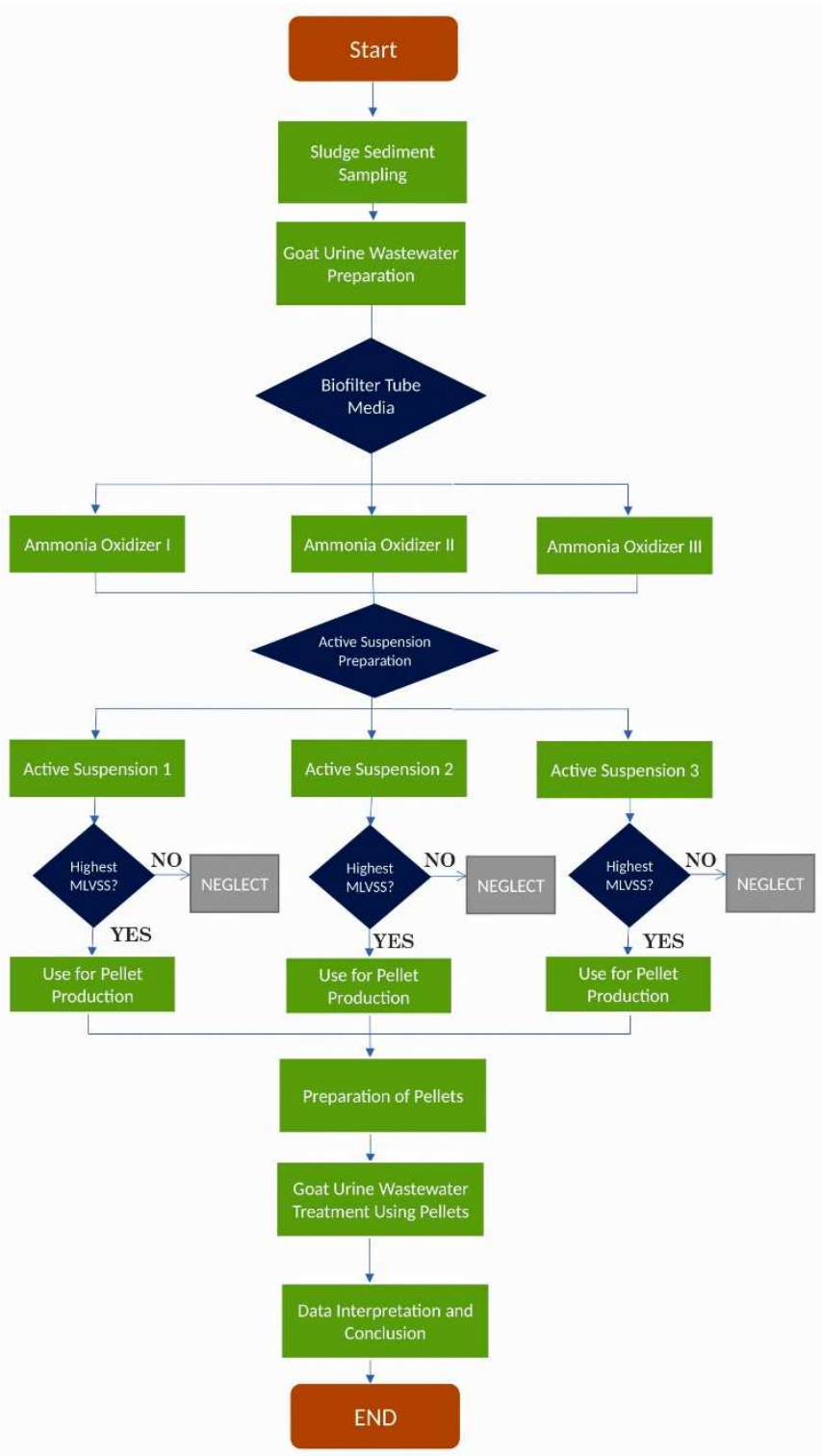

Fig. 1 Research Methodology Flowchart

\section{A. Sludge Sediment Sampling}

The sludge sediment that was used as a source of active suspension cultivation was taken from the disposal area of livestock waste in Badung river water bodies on Jl. Maruti No. 5, North Denpasar. Sediment sampling was randomly carried out at several points as much as 10 grams per point was taken using a small shovel with a depth of $\pm 10 \mathrm{~cm}$ from the soil surface then the samples were mixed together. The sediment samples were taken to the laboratory for active suspension seeding.

\section{B. Goat Urine Wastewater Preparation}

Goat urine samples were taken from one of the goat farms on Jl. Maruti No. 5, North Denpasar. The goat urine was placed in a bottle/jerry can then it was closed tightly. The urine was then filtered with gauze to remove impurities in the form of solids that can interfere with the processing process. Initial measurement was then conducted in order to identify the initial concentration of ammonia, nitrite, nitrate, the color and odor of the observed goat urine samples. 


\section{Biofilter Tube Media Preparation}

The biofilter processing tub was made of a beaker glass with a height of $14.5 \mathrm{~cm}$ and a diameter of $12 \mathrm{~cm}$ with a volume of $1000 \mathrm{~mL}$. Three biofilter basins were prepared for repeated treatment. Each tub was equipped with an aerator to supply air to the tub. The air supply can support microorganisms to decompose the substrate. Three biofilter media were divided as follows:

1) Ammonia Oxidizer I Media: Ammonia oxidizers I media was made from $\mathrm{K}_{2} \mathrm{HPO}_{4}(100 \mathrm{mg}), \mathrm{NaHCO}_{3}(1225 \mathrm{mg})$, $\mathrm{Na}_{2} \mathrm{CO}_{3}(359 \mathrm{mg}), \mathrm{MgSO}_{4} .7 \mathrm{H}_{2} \mathrm{O}(60 \mathrm{mg}), \mathrm{FeSO}_{4} .7 \mathrm{H}_{2} \mathrm{O}(40$ $\mathrm{mg}), \mathrm{CaCl}_{2} \cdot 2 \mathrm{H}_{2} \mathrm{O}(40 \mathrm{mg})$, and as a source of nitrogen $\left(\mathrm{NH}_{4}\right)_{2} \mathrm{SO}_{4}(300 \mathrm{mg})$ was added, then all the ingredients are dissolved in distilled water to a volume of $1000 \mathrm{~mL}$ in a beaker.

2) Ammonia Oxidizer II Media: Ammonia oxidizers II media was made from 10 grams of NPK fertilizer, 10 grams of glucose, and 5 grams of $\mathrm{NH}_{4} \mathrm{Cl}$ powder. All of these materials were placed into a beaker glass and diluted with distilled water until the volume reached $1000 \mathrm{~mL}$, then stirred until homogeneous [7]

3) Ammonia Oxidizers III Media: Ammonia oxidizers III media was made from 5 grams of urea, 2.5 grams of $\mathrm{KCl}$, and 2.5 grams of TSP, and 10 grams of glucose. All of these materials were then poured into a beaker glass and diluted using distilled water until the volume reached $1000 \mathrm{~mL}$, then stirred until homogeneous.

\section{Ammonia Oxidizer Active Suspension Production}

A total of 3 clean beaker glasses of $2 \mathrm{~L}$ size were prepared and labeled SA1 (active suspension 1), SA2 (active suspension 2), and SA3 (active suspension 3). To beaker SA1 was added $1000 \mathrm{~mL}$ of ammonia oxidizers I media which had been made as much as $1000 \mathrm{~mL}$, to beaker SA2 was added $1000 \mathrm{~mL}$ of ammonia oxidizers II medium, and to beaker, SA3 has added $1000 \mathrm{~mL}$ of ammonia oxidizers III medium. Furthermore, each beaker was added to the sediment sample, which had been taken as much as 10 grams. Then the three beaker glasses were aerated using an aerator with a hose, then covered with gauze and tied with rubber. The growth of bacterial isolates was observed by measuring the MLVSS (Mixed Liquor Volatile Suspended Solid) value for 3 days until the MLVSS reached $2000 \mathrm{mg} / \mathrm{L}$ [8]. Previous research used seed sludge with MLVSS concentration around 1260$1550 \mathrm{mg} / \mathrm{L}$ [9] and $2500 \mathrm{mg} / \mathrm{L}$ [10]. The active solution of ammonia oxidizers with the highest MLVSS value would be used to manufacture pellets, which could be applied to process goat urine into $\mathrm{N}$ fertilizer after all.

\section{E. Preparation of Pellets by Adding an Active Solution of Ammonia Oxidizers}

Pellets were made from 500 grams of tofu pulp and 250 grams of corn flour. The active solution of ammonia oxidizers with the highest MLVSS value was prepared as a substitute for water. Then all the ingredients are mixed to make it evenly distributed. Then the ingredients are added with an active solution of ammonia oxidizers until the ingredients take the form of a dough. Then the dough is put into a mold using a pve pipe measuring $3 \mathrm{~cm}$ long and $1.5 \mathrm{~cm}$ in diameter.
Afterwards, the pellets were removed from the mold then dried out by aeration process for three days until the water content of the pellets was less than 10\%; high-quality pellet was achieved at water content around 5-15\% [11], [12]. Materials as pellets should be sufficiently aerated to allow the air exchange [13]. However, other studies showed that the increase of the air-filled porosity can reduce moisture content and then the rates of nitrification [14]. A positive correlation between pellets durability and optimal moisture of $10 \%$ was found, which was caused by temperature, pressure and chemical composition of raw material that acts like a binding agent to increase pellets quality [15].

\section{F. Goat Urine Wastewater Treatment Using Pellets to Produce N-Fertilizer}

Treatment of goat urine was carried out after the immobilized pellets of the active ammonia oxidizers were considerably dry and ready for use. The urine wastewater was filtered first with gauze to remove impurities in the form of solids that are mixed into the urine. Then the urine is put into a processing tub with a volume of $1000 \mathrm{~mL}$ as many as 3 tanks and each tub containing $500 \mathrm{~mL}$ of urine. Tube 1 (pellet a) was added with $10 \%(\mathrm{w} / \mathrm{v})$ of pellets, for about 50 grams of pellets in $500 \mathrm{~mL}$ of goat urine, then tube 2 (pellet b) was added with pellets of $20 \%(\mathrm{w} / \mathrm{v})$, which was 100 grams of pellets in $500 \mathrm{~mL}$ of goat's urine, and tube 3 (pellet c) was added $30 \%(\mathrm{w} / \mathrm{v})$ pellets, which was about 150 grams of pellets in $500 \mathrm{~mL}$ of goat urine. Processing is carried out aerobically by providing oxygen continuously through an aerator so that the nitrification process can occur, namely changing ammonia to nitrate. All the tanks were left to rest for the specified time. Then urine samples were taken for analysis of ammonia, nitrite, and nitrate. Sampling for ammonia, nitrite, and nitrate concentrations was carried out at 8, 12, 18, and 24 hours. Measurements were made to examine the maximum ability of the pellets used to oxidize ammonia to nitrate so that the optimal time and optimal dosage of the pellets used in the processing of urine into $\mathrm{N}$ fertilizer can be determined.

\section{RESULTS AND DISCUSSION}

\section{A. Microorganisms Growth in Active Suspension}

MLVSS value was calculated to discover which active suspension showed the best performance, which was indicated by a higher MLVSS value, before preparing the pellets. The MLVSS value shows volatile organic compounds. The number represents the number of microorganisms contained in it because volatile organic materials such as carbohydrates, proteins, glucose, and others are present in microbes so that the number can represent the number of microbes in the active suspension. The greater MLVSS value, the better the pellets would perform. The optimal time for nursery is seen from the highest MLVSS value, because the highest MLVSS value indicated the peak of the growth of microorganisms [16]. At that time, the active solution of ammonia oxidizers was ready for use and then immobilized into the pellets. Fig. 2 showed microorganisms' growth curve in active suspension for SA1 (active suspension 1), SA2 (active suspension 2), and SA3 (active suspension 3). 


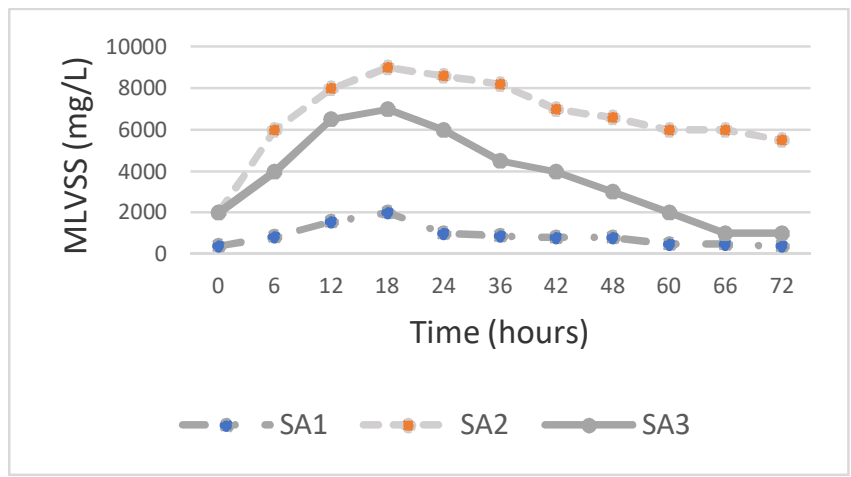

Fig. 2 Microorganism's growth profile for each liquid nutrient media composition

\section{B. Physical Characteristics and Pellet's Water Content}

Compared to a previous study from Han et al. [17]which mixed selenium-wolfram solution (SWS), trace element solution, $\mathrm{KH}_{2} \mathrm{PO}_{4}, \mathrm{KCl}, \mathrm{MgSO}_{4} .7 \mathrm{H}_{2} \mathrm{O}, \mathrm{NaCl}$, and $\mathrm{CaCO}_{3}$ to create ammonia-oxidizing microbes cultivation media, this research used pellets as a source of nutrients which were made from organic materials such as tofu and corn flour. It was mixed with an active solution of ammonia oxidizers. The resulting pellets were tubular, $\pm 3 \mathrm{~cm}$ long, and $\pm 1 \mathrm{~cm}$ in diameter. The pellets were faded yellow in color, with a strong odor. The average weight of one pellet was \pm 2.00 grams. In making pellets, several parameters must be tested so that the pellets can be used for the next process. The parameter tested was the water content in the pellets.

Table 1 shows that the average water content of pellets obtained was $8.55 \%$, which means that it has met the quality standards for making pellets, which is no more than $15 \%$. Otherwise, the water would damage pellets during storage [15]. The same water content level was also applied by Hudakorn et al. [18] when producing biomass pellets using water hyacinth fiber. Biomass pellets made by water hyacinth fiber with 10:90 water ratio showed optimal conditions and passed the PFI standard of moisture content below $10 \%$.

TABLE I

Pellet Water Content ObServation Results

\begin{tabular}{lll}
\hline Pellet & Water Content(\%) & Advisability (\%) \\
\hline $\mathrm{a}$ & 8.35 & $<10$ \\
$\mathrm{~b}$ & 8.4 & $<10$ \\
$\mathrm{c}$ & 8.9 & $<10$ \\
Average & 8.55 & \\
\hline
\end{tabular}

A good drying process influenced this result. The pellets' quality was influenced by binder contents, binder types, and moisture contents [19]. The water content that meets the quality standards will prevent the pellets from getting infested with mushrooms and fungi so that the storage time will be more optimum.

\section{Changes in Ammonia Concentration at Various Pellet Doses in Goat Urine Treatment into $N$-fertilizer.}

The measurement of ammonia concentration in this study was accomplished using the Nessler method by spectrophotometry. The principle of measuring ammonia using the Nessler method is the reaction with Nessler's reagent $\left(\mathrm{K}_{2} \mathrm{HgI}_{4}\right)$, which, when it is reacted with ammonia in alkaline conditions, it will form a colloid dispersion that has brown and yellow in color. The color intensity will be directly proportional to the concentration of ammonia in the sample [20]. By measuring ammonia with UV-Vis spectra in goat urine samples with a maximum wavelength of $412.1 \mathrm{~nm}$, the absorbance value of each sample can be obtained. The absorbance value can be used to determine the concentration of the sample by calculating it according to the regression equation obtained, namely $y=0.2021 x+0.0031$.

Changes in ammonia concentration in every pellet dosage can be seen in Fig.3. From that figure, it can be deduced that the increasing pellet dosage had successfully decreased ammonia concentration in goat urine wastewater. Among all of the pellet's type, pellet $b$ was showing the best performance.

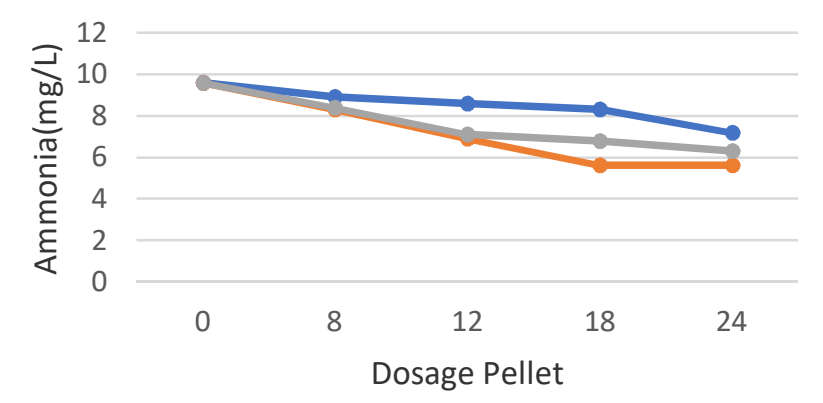

Fig. 3 Ammonia degradation in pellet doses at 10, 20 and $30 \%(w / v)$

Ammonia concentration removal data were then analyzed statistically using IBM SPSS 23.0 software. Homogeneity test of changes in ammonia concentration at various pellet doses showed a homogeneous data distribution with $\mathrm{p}=0.219$ ( $\mathrm{p}>$ $0.05)$ value. The data is homogeneous and normally distributed so that it is continued with the ANOVA two-way test to determine whether there is a significant difference between dosage variations and processing time on changes in ammonia concentration. Variation of pellet dosage on changes in ammonia concentration resulted in a significance value of $p<0.05$, which means that variations in pellet dose had a significant effect. The effect of the treatment period on changes in ammonia concentration resulted in a p-value $<0.05$, so it implied that the treatment period had a significant effect on ammonia concentration changes. The longer treatment period (processing time) would result in better ammonia removal. According to Caceres et al. [13], an appropriate condition for nitrifiers to perform nitrification could take longer due to several possible inhibitors such as high temperature, low dissolved oxygen, and competition among various groups of nitrifying bacteria.

\section{Decreasing Nitrite Concentrations at Various Pellet Doses in the Process of Processing Goat Urine into $N$ Fertilizer}

The principle of measuring nitrite in this study is that in an acidic atmosphere with a $\mathrm{pH}$ of 2.0-2.5, nitrite will react with sulfanilamide and N-(1-naphthyl ethylene diamine dihydrochloride (NED dihydrochloride). The reaction will form azo compounds with a purplish red color (SNI 066989.9-2004). Measurement of nitrite concentration in goat urine samples is carried out at a maximum wavelength of 518 
$\mathrm{nm}$. The reduction in nitrite levels occurs in livestock wastewater at a rate following the equation $y=-4,56 x+39,57$. Fig. 4 shows a decrease in the concentration of nitrite in the three samples, namely pellet $a$, pellet $b$, and pellet $c$. The sample performed the highest nitrite removal with a pellet dose of $20 \%(\mathrm{w} / \mathrm{v})$ (pellet $\mathrm{b}$ ) and the measurement time at 18 hours, with an average nitrite concentration of three repetitions of $2.3992 \mathrm{mg} / \mathrm{L}$. The pellet dose was $10 \%(\mathrm{w} / \mathrm{v})$ (pellet a) decreased the nitrite concentration of three repetitions of $4.2637 \mathrm{mg} / \mathrm{L}$.

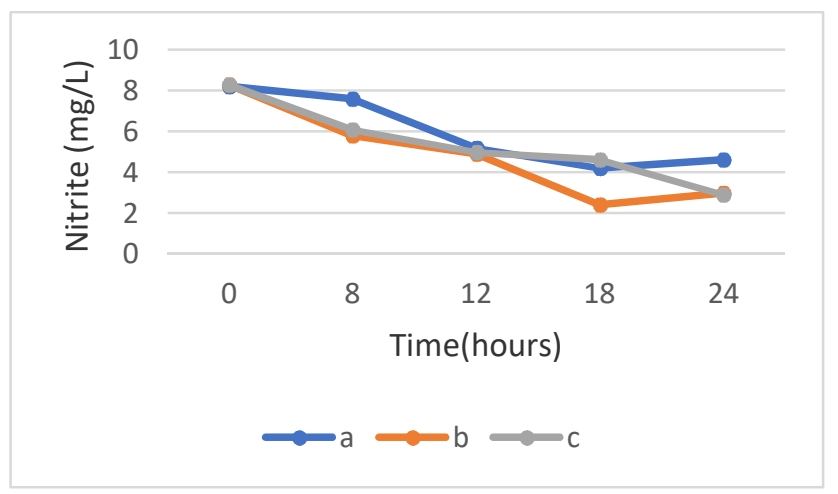

Fig. 4 Nitrite concentration removal in livestock wastewater for each pellet dosage.

Samples with a pellet dose of $30 \%(w / v)$ (pellet c) experienced a modest decrease in nitrite concentration at 24 hours with an average concentration of three repetitions of $2.9084 \mathrm{mg} / \mathrm{L}$. The decrease in nitrite concentration occurs due to the oxidation process of ammonia with the help of immobilized bacteria in the pellet and with the help of oxygen through the aeration process. However, the amount of nitrite obtained is not much because the nitrite produced will quickly undergo an oxidation process by aerobic bacteria to become nitrate, due to the amount of oxygen required to oxidize nitrite to nitrate is less than the amount of oxygen required to oxidize ammonia to nitrite, so nitrite becomes unstable and tends to have low concentrations.

The decrease in nitrite concentration occurs due to the oxidation process of ammonia with the help of immobilized bacteria in the pellet and with the help of oxygen through the aeration process, but the amount of nitrite obtained is not much because the nitrite produced will quickly undergo an oxidation process by aerobic bacteria to become nitrate, due to the amount of oxygen. It is required to oxidize nitrite to nitrate is less than the amount of oxygen required to oxidize ammonia to nitrite, so nitrite becomes unstable and tends to have low concentrations. The availability of oxygen for nitrite-oxidizing bacteria was lower than ammonia-oxidizing bacteria. Therefore ammonia-oxidizing bacteria was higher than nitrite-oxidizing bacteria, leading to a larger portion of organic metabolite synthesis [21].

From the results of measuring the nitrite concentration, it can be seen that the optimal reduction in nitrite concentration is in samples with a pellet dose of $20 \%(\mathrm{w} / \mathrm{v})$ (pellet b) with the treatment duration of 18 hours. This phenomenon happened due to the optimal activity of microorganisms and the need for sufficient oxygen for the oxidation process. Samples with a pellet dose of $10 \%(\mathrm{w} / \mathrm{v})$ (pellet a) were less than optimal in reducing nitrite concentrations because the number or population of microorganisms in the sample was small so that the oxidation process was aggravating, whereas at the pellet dose of $30 \%(\mathrm{w} / \mathrm{v})$ (pellet c) the microorganisms were also ineffective in reducing nitrite concentration. After all, the population of microorganisms was huge so that the oxygen demand for the oxidation process is insufficient and the results obtained are less than optimal. In addition, the pellet dose of $30 \%(\mathrm{w} / \mathrm{v})$ has the lowest $\mathrm{pH}$ value than samples with other pellet doses, so that the nitrification process that occurs is less than optimal because at a $\mathrm{pH}$ that is too low the effectiveness of nitrification will decrease. The statistical analysis results of changes in nitrite concentration obtained a significance value on the homogeneity test of $\mathrm{p}=$ 0.833 ( $p>0.05)$, which means that the data is homogeneous. The normality test conducted shows that the data is normally distributed. The variation in pellet dose had a significant effect on changes in nitrite concentration with a significance value of $\mathrm{p}$. Processing time had a significant effect on changes in nitrite concentration with $\mathrm{p}<0.05$.

\section{E. Changes in nitrate concentrations at various pellet doses in the processing of goat urine into $N$ fertilizer.}

Nitrate concentration measurements were carried out using the brucine sulfate method spectrophotometrically. The principle of measuring the concentration of nitrate with the brucine sulfate method is the reaction of brucine with nitrate, which will form a yellow compound where the heat level of the solution influences the reaction rate. Heating is done by adding concentrated sulfuric acid. The absorbance of this compound was then measured at a maximum wavelength of $462.1 \mathrm{~nm}$. The light intensity absorbed by the solution will be proportional to the concentration of nitrate in the sample, so in other words, the darker the yellow color of the solution will indicate the higher the nitrate content. Measurement of the sample was carried out at the maximum wavelength so that the absorbance of each sample was obtained, then the calculation of the nitrate concentration was carried out with the regression equation $y=0.0208 x+0.0101$. The results of measuring the concentration of nitrate above can make a curve for changes in the concentration of nitrate at various pellet doses in the process of processing goat urine into $\mathrm{N}$ fertilizer, as in Fig.5.

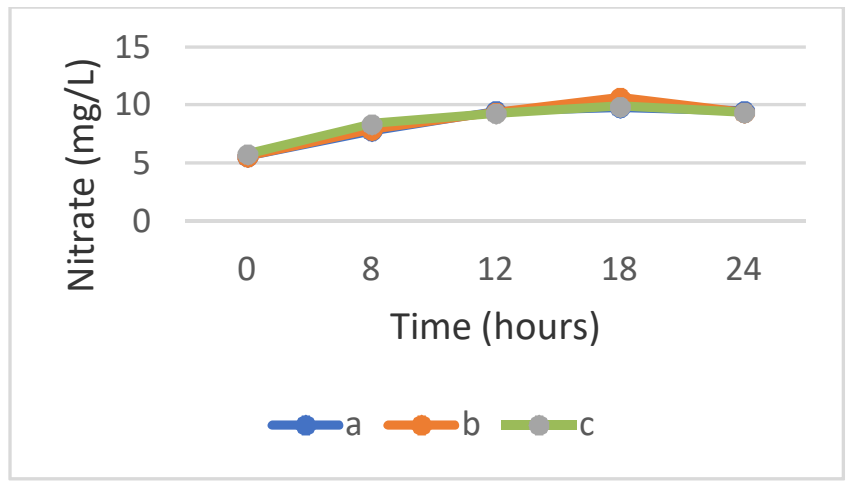

Fig. 5 The increasing nitrate concentration for each pellet's dosage.

The data on changes in nitrate concentration were analyzed statistically with the significance test results for homogeneity of $p=0.552(p>0.05)$, which means that the data is homogeneous. Variation in pellet dose had a significant effect 
on changes in nitrate concentration with a significance value of $p<0.05$. The effect of processing time on changes in nitrate concentration has a significance value of $p<0.05$, so processing time has a significant effect.

\section{F. Changes in $\mathrm{pH}$ at various pellet doses in goat urine processing into $N$ fertilizer.}

One of the factors that influence the nitrification process is the $\mathrm{pH}$ value. The optimum $\mathrm{pH}$ value for the nitrification process is between 7.5-8.5 [22]. Nitrifying bacteria are very sensitive to $\mathrm{pH}$ values. At $\mathrm{pH} 6.3$ - 6.7, the nitrification process will slow down, then at $\mathrm{pH} 5-5.5$ the nitrification process will stop. No change in ammonium, nitrite, and nitrate concentrations at $\mathrm{pH} 5$ is noticeable, which indicated a strong inhibition of ammonium oxidation at pH 5 [23]. The results of $\mathrm{pH}$ measurements during the processing of goat urine into $\mathrm{N}$ fertilizer are presented in Fig. 5.

In Fig. 6, it can be seen that the $\mathrm{pH}$ value of the three samples with a pellet dose of $10 \%(\mathrm{w} / \mathrm{v}), 20 \%(\mathrm{w} / \mathrm{v})$, and $30 \%$ $(\mathrm{w} / \mathrm{v})$ has decreased over time. The treatment hours resemble the stages of the nitrification process. The $\mathrm{pH}$ value decreases in the first hour as the ammonia concentration decreases. In addition to producing $\mathrm{NO}_{2}^{-}$ions, the nitrification reaction in the nitritation stage will also release $\mathrm{H}^{+}$and $\mathrm{H}_{2} \mathrm{O}$ ions. This $\mathrm{H}^{+}$ ion causes a decrease in $\mathrm{pH}$. This is because $\mathrm{H}^{+}$ions are acidic so that the $\mathrm{pH}$ value decreases [24].

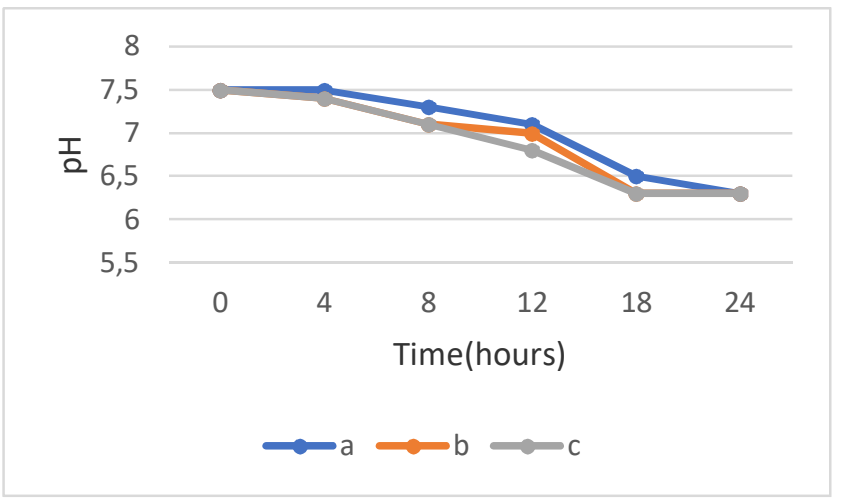

Fig. $6 \mathrm{pH}$ changes during nitrification

If the ammonia increases, the $\mathrm{pH}$ value will also substantially increase. At $\mathrm{pH} 7$ or less, most of the ammonia will be ionized and vice versa at a $\mathrm{pH}$ greater than 7 , ammonia is not ionized and is toxic, and the amount is more. The $\mathrm{pH}$ value can also decrease if there is a process of nitrite and nitrate formation [25], with the following reactions:

$$
\begin{gathered}
\mathrm{NH} 4++3 / 2 \mathrm{O} 2 \rightarrow \mathrm{NO} 2-+2 \mathrm{H}++\mathrm{H} 2 \mathrm{O} \\
\mathrm{NO} 2-+1 / 2 \mathrm{O} 2 \rightarrow \mathrm{NO} 3-
\end{gathered}
$$

The above reaction shows that each mole of ammonium is oxidized to produce 2 moles of hydrogen ions, which results in a lower $\mathrm{pH}$ value. This shows that nitrifying bacteria are very sensitive to $\mathrm{pH}$ values. The decrease in $\mathrm{pH}$ value is also caused by the presence of carbon dioxide $\left(\mathrm{CO}_{2}\right)$, which is produced from the process of breaking down urea in water contained in goat urine with the help of the urease enzyme, which is owned by nitrifying bacteria, with the following reaction:

$$
\mathrm{CO}(\mathrm{NH} 2) 2+\mathrm{H} 2 \mathrm{O} \rightarrow 2 \mathrm{NH} 3+\mathrm{CO} 2
$$

Carbon dioxide will react with water molecules to form carbonic acid and produce hydrogen ions in the goat urine sample to be acidic. The reactions that occur is [26] :

$$
\mathrm{CO} 2+\mathrm{H} 2 \mathrm{O} \rightarrow \mathrm{HCO} 3-+\mathrm{H}+
$$

The solubility of carbon dioxide in the water contained in goat urine can be affected by temperature. The increase in temperature will cause $\mathrm{CO}_{2}$ gas to come out of urine, so that the increase in temperature will cause the $\mathrm{CO}_{2}$ level to be lower. Conversely, the lower the temperature, the more $\mathrm{CO}_{2}$ will dissolve and increase the hydrogen level in the urine so that the urine will have an acidic $\mathrm{pH}$. The $\mathrm{pH}$ value decreases over time, so it can be said that the longer the nitrification process is less optimal because the optimal $\mathrm{pH}$ of the nitrification process is at $\mathrm{pH} 7.5-8.5$. The decrease in the $\mathrm{pH}$ value at each pellet dose in the data above does not reach $\mathrm{pH}$ 5 so that the nitrification process has not been stopped. It is just that the ongoing process has decreased effectiveness and the result of ammonia oxidation is not optimal at too low a $\mathrm{pH}$. Low $\mathrm{pH}$ has an inhibition effect on ammonia-oxidizing bacteria [27].

The lowest average $\mathrm{pH}$ value for samples with a pellet dose of $10 \%(\mathrm{w} / \mathrm{v})$ and $20 \%(\mathrm{w} / \mathrm{v})$ is 6.6 at the 24 th-hour measurement, while for samples with a pellet dose of $30 \%$ $(\mathrm{w} / \mathrm{v}))$ the lowest average $\mathrm{pH}$ value reaches 6.4 which means that the nitrification process can still take place and has not stopped, but its effectiveness has decreased. If the $\mathrm{pH}$ is less than 6.4 , there will be no growth of autotrophic bacteria (nitrifying bacteria) [28].

\section{CONCLUSION}

According to the explanation above, it can be concluded that the best medium for ammonia oxidizers pellets to undergo nitrification process for goat urine treatment is Ammonia Oxidizer Media II (media for pellet b) which was built of 10 grams of NPK fertilizer, 10 grams of glucose, and 5 grams of $\mathrm{NH}_{4} \mathrm{Cl}$ powder. Then, the dosage $\mathrm{B}$ in tube 2 , which contained pellets of $20 \%(\mathrm{w} / \mathrm{v})$ (pellet b) consisted of 100 grams of pellets in $500 \mathrm{~mL}$ of goat's urine, was the best dosage that was shown to effectively reduce ammonia, increase nitrate levels and reduce nitrite levels and the ability to withstand neutral $\mathrm{pH}$ for up to 18 hours. Finally, amongst all pellets' dosages, the highest nitrite removal was performed by the sample with a pellet dose of $20 \%(\mathrm{w} / \mathrm{v})$ (pellet $\mathrm{b}$ ) and the measurement time at 18 hours, with an average nitrite concentration of three repetitions of $2.3992 \mathrm{mg} / \mathrm{L}$. This research has successfully addressed the correlation between the performance of localmaterials-based pellets to undergo nitrification and the impact of $\mathrm{pH}$ level on nitrification. However, there is still a gap in this research that has not been observed profoundly, namely the impact of the other environmental factors such as temperature, dissolved oxygen, alkalinity, and organic matter degradation on the nitrification process using pellets.

\section{ACKNOWLEDGMENT}

We are grateful to the Laboratory of Environmental Chemistry, Udayana University, for the humongous aid to permit researchers conducting this research. We are obliged to the Directorate of Higher Education of the Ministry of Education and Culture of Indonesia to support this research. 


\section{REFERENCES}

[1] Y. Hu, H. Cheng, and S. Tao, "Environmental and human health challenges of industrial livestock and poultry farming in China and their mitigation," Environment International. 2017, doi: 10.1016/j.envint.2017.07.003.

[2] J. Lv, Y. Liu, J. Feng, Q. Liu, F. Nan, and S. Xie, "Nutrients removal from undiluted cattle farm wastewater by the two-stage process of microalgae-based wastewater treatment," Bioresour. Technol., 2018, doi: 10.1016/j.biortech.2018.05.085.

[3] K. H. Cho, J. O. Kim, S. Kang, H. Park, S. Kim, and Y. M. Kim, "Achieving enhanced nitrification in communities of nitrifying bacteria in full-scale wastewater treatment plants via optimal temperature and pH," Sep. Purif. Technol., 2014, doi: 10.1016/j.seppur.2014.06.027.

[4] L. Wang et al., "Response Characteristics of Nitrifying Bacteria and Archaea Community Involved in Nitrogen Removal and Bioelectricity Generation in Integrated Tidal Flow Constructed Wetland-Microbial Fuel Cell," Front. Microbiol., 2020, doi: 10.3389/fmicb.2020.01385.

[5] Y. Zhang et al., "Association of robust nitrogen removal with spatiotemporal nitrifying bacterial community dynamics in a new bioreactor for treatment of simulated livestock wastewater with high ammonia content," J. Chem. Technol. Biotechnol., 2019, doi: 10.1002/jctb.5809.

[6] M. B. Vanotti and P. G. Hunt, "Nitrification treatment of swine wastewater with acclimated nitrifying sludge immobilized in polymer pelletsVanotti, M. B., \& Hunt, P. G. (2000). Nitrification treatment of swine wastewater with acclimated nitrifying sludge immobilized in polymer pellets.," Trans. Am. Soc. Agric. Eng., 2000, doi: 10.13031/2013.2719.

[7] I. G. A. L. Pradnyadari, I. W. B. Suyasa, and N. G. A. M. D. A. Suastuti, "Penyisihan Amonia, Nitrit Dan Nitrat Dengan Biofilter Menggunakan Plastik Bekas Sebagai Media Penopang Biofilm,” J. Media Sains, 2018

[8] N. Sudaryati, I. Kasa, and I. Budiarsa Suyasa, "Pemanfaatan Sedimen Perairan Tercemar Sebagai Bahan Lumpur Aktif Dalam Pengolahan Limbah Cair Industri Tahu," Ecotrophic J. Environ. Sci., 2012.

[9] S. Huang et al., "Effects of low-intensity ultrasound on nitrite accumulation and microbial characteristics during partial nitrification," Sci. Total Environ., 2020, doi: 10.1016/j.scitotenv.2019.135985.

[10] X. Zheng et al., "Inhibition of free ammonia to the granule-based enhanced biological phosphorus removal system and the recoverability," Bioresour. Technol., 2013, doi: 10.1016/j.biortech.2013.08.100.

[11] I. Obernberger and G. Thek, "Physical characterisation and chemical composition of densified biomass fuels with regard to their combustion behaviour," Biomass and Bioenergy, 2004, doi: 10.1016/j.biombioe.2003.07.006.

[12] R. Labbé, S. Paczkowski, V. Knappe, M. Russ, M. Wöhler, and S. Pelz, "Effect of feedstock particle size distribution and feedstock moisture content on pellet production efficiency, pellet quality, transport and combustion emissions," Fuel, 2020, doi: 10.1016/j.fuel.2019.116662.
[13] R. Cáceres, K. Malińska, and O. Marfà, "Nitrification within composting: A review," Waste Management. 2018, doi: 10.1016/j.wasman.2017.10.049.

[14] Z. Y. Sun, J. Zhang, X. Z. Zhong, L. Tan, Y. Q. Tang, and K. Kida, "Production of nitrate-rich compost from the solid fraction of dairy manure by a lab-scale composting system," Waste Manag., 2016, doi: 10.1016/j.wasman.2016.03.002.

[15] N. Ungureanu, V. Vladut, G. Voicu, M. N. Dinca, and B. S. Zabava, "Influence of biomass moisture content on pellet properties - Review," 2018, doi: 10.22616/ERDev2018.17.N449.

[16] T. Allegue, A. Arias, N. Fernandez-Gonzalez, F. Omil, and J. M. Garrido, "Enrichment of nitrite-dependent anaerobic methane oxidizing bacteria in a membrane bioreactor," Chem. Eng. J., 2018, doi: 10.1016/j.cej.2018.04.134.

[17] P. Han et al., "N2O and NOy production by the comammox bacterium Nitrospira inopinata in comparison with canonical ammonia oxidizers," Water Res., 2021, doi: 10.1016/j.watres.2020.116728.

[18] T. Hudakorn and N. Sritrakul, "Biogas and biomass pellet production from water hyacinth," 2020, doi: 10.1016/j.egyr.2019.11.115.

[19] A. A. Abdul-Rahman, N. Yusoff, and A. Abd-Rahman, "The effects of biomass binders and moisture content on the mechanical durability of rice husk pellets," 2020, doi: 10.1088/1757-899X/736/5/052013.

[20] M. Y. Patri, "Penentuan Kadar Ammonia (NH3) pada Limbah Cair K36 dalam Rangka Pengendalian Pencemaran Lingkungan," ALKIMIA J. Ilmu Kim. dan Terap., 2019, doi: 10.19109/alkimia.v2i2.2998.

[21] A. Sepehri and M.-H. Sarrafzadeh, "Activity enhancement of ammonia-oxidizing bacteria and nitrite-oxidizing bacteria in activated sludge process: metabolite reduction and $\mathrm{CO} 2$ mitigation intensification process," Appl. Water Sci., 2019, doi: 10.1007/s13201019-1017-6.

[22] F. Huang, L. Pan, N. Lv, and X. Tang, "Characterization of novel Bacillus strain N31 from mariculture water capable of halophilic heterotrophic nitrification-aerobic denitrification," J. Biosci. Bioeng., 2017, doi: 10.1016/j.jbiosc.2017.06.008.

[23] T. T. H. Le, J. Fettig, and G. Meon, "Kinetics and simulation of nitrification at various $\mathrm{pH}$ values of a polluted river in the tropics," Ecohydrol. Hydrobiol., 2019, doi: 10.1016/j.ecohyd.2018.06.006.

[24] E. Hopkins, T. Sanvictores, and S. Sharma, "Physiology, Acid Base Balance," Treasure Isl. StatPearls Publ., 2020.

[25] P. S. Romer Present, A. Zare, and R. C. Cohen, "The changing role of organic nitrates in the removal and transport of NOx," Atmos. Chem. Phys., 2020, doi: 10.5194/acp-20-267-2020.

[26] S. K. Reddy and S. Balasubramanian, "Carbonic acid: Molecule crystal and aqueous solution," Chem. Commun., 2014, doi: $10.1039 / \mathrm{c} 3 \mathrm{cc} 45174 \mathrm{~g}$.

[27] Y. Zou, Z. Hu, J. Zhang, H. Xie, C. Guimbaud, and Y. Fang, "Effects of $\mathrm{pH}$ on nitrogen transformations in media-based aquaponics," Bioresour. Technol., 2016, doi: 10.1016/j.biortech.2015.12.079.

[28] A. Anisa and W. Herumurti, "Pengolahan Limbah Domestik Menggunakan Moving Bed Biofilm Reactor (MBBR) dengan Proses Aerobik-Anoksik untuk Menurunkan Konsentrasi Senyawa Organik dan Nitrogen," J. Tek. ITS, 2017, doi: 10.12962/j23373539.v6i2.25166. 